
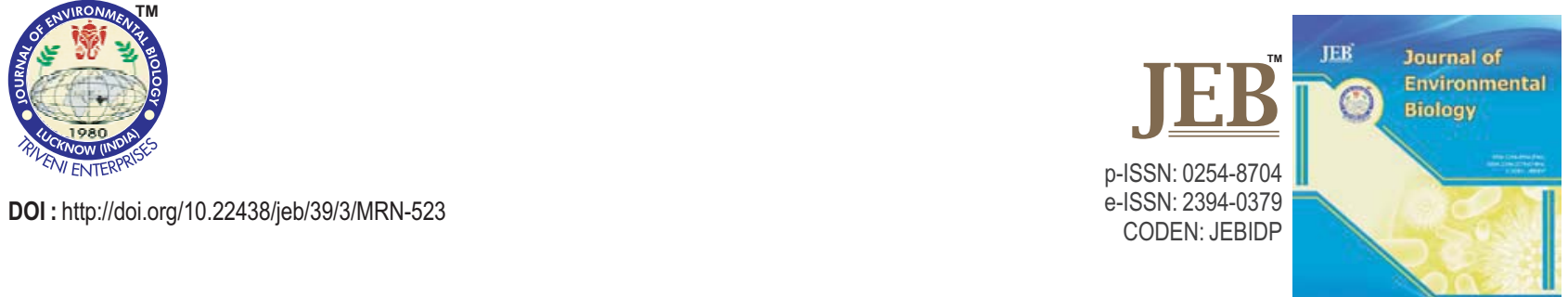

\title{
Study on the activity and diversity of bacteria in a New Gangetic alluvial soil (Eutrocrept) under rice-wheat- jute cropping system
}

Authors Info

S. Biswas ${ }^{1,2 *}$, D.K. Kundu', S.P. Mazumdar ${ }^{2}$, A.R. Saha', B. Majumdar', A.K. Ghorai', D. Ghosh', A.N. Yadav ${ }^{3}$ and A.K. Saxena ${ }^{3}$

'Division of Soil Science and Agricultural Chemistry, ICAR-Indian Agricultural Research Institute, New Delhi-110 012, India

${ }^{2}$ Crop Production Division, ICARCentral Research Institute for Jute and Allied Fibres, Barrackpore, Kolkata-700 120, India

${ }^{3}$ Division of Microbiology, ICAR-Indian Agricultural Research Institute, New Delhi-110 012, India

${ }^{*}$ Corresponding Author Email : sunandabiswas13@gmail.com

Key words

Bacteria

Diversity analysis

Inceptisol

PCR-RFLP

Soil enzyme

Publication Info

Paper received : 30.11 .2016

Revised received : 24.04.2017

Re-revised received : 30.06.2017

Accepted : 19.08.2017

\begin{abstract}
Aim : Soil microorganisms play an important role in sustaining soil health and long term productivity by performing major soil functions like decomposition of organic matter, nutrient cycling and formation of soil aggregate etc. The main objective of the present investigation was to study the long term (42 years) effect of different management practices on the activity and diversity of bacteria isolated from a New Gangetic alluvial soil with rice-wheat-jute cropping system.
\end{abstract}

Methodology : Soil samples were collected from five different management practices viz., fallow, control, $100 \%$ recommended dose of NPK, $150 \%$ of recommended dose of NPK and $100 \%$ recommended dose of NPK plus farmyard manure under 42 years old long term fertilizer experiment with rice-wheat-jute cropping system at Central Research Institute for Jute and Allied Fibres, Barrackpore, West Bengal. Soil samples were analysed for microbial populations using various media, microbial biomass carbon, dehydrogenase, FDA hydrolase, acid and alkaline phosphatase activity of soil. Bacterial diversity was analysed by PCR-RFLP of genomic DNA of isolates using Hae III restriction enzyme.

Results : Enumeration of soil microbes was done by standard method of serial dilution and spread plate technique using different media. Highest bacterial population was found with $100 \%$ $\mathrm{NPK}+\mathrm{FYM}$ treatment on nutrient agar Study on activity and diversity of soil microorganisms

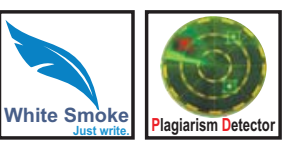

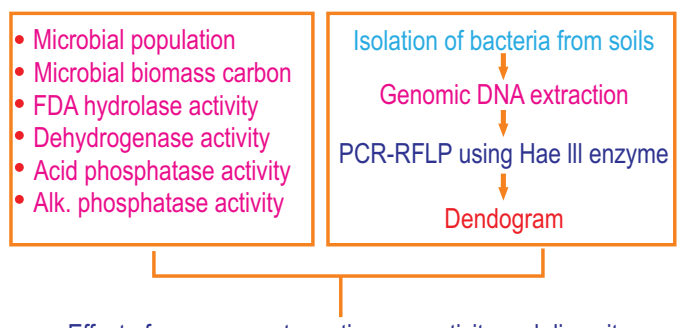

Effect of management practices on activity and diversity

Overall effect on soil health of soil microorganisms media. Microbial biomass carbon content under different management practices varied from 221 to $447 \mathrm{mg} \mathrm{kg}^{-1}$ soil and highest was found with $100 \%$ NPK+FYM treatment. For all the four enzyme activities, highest value was found with integrated treatment and lowest was with control treatment. Dendrogram derived from the distance matrix by UPGMA, a total of 35 clusters were recorded for 59 bacterial isolates.

Interpretation : Integrated management practices with balanced use of mineral fertilizers and organic manures sustain the microbial activity and diversity and maintain soil health. 


\section{Introduction}

The activity and diversity of soil bacteria, an indicator of soil health is mostly affected by different management practices followed in the crop fields. The factors like cropping system, fertilizer and manure application etc., affects the soil microbial growth, activity and diversity. Microbial biomass carbon and enzyme activity increases with continuous application of fertilizer or organic manure (Zhao et al., 2016). Enzymes are important soil components involved in dynamics of soil nutrient transformations and enzyme activity is considered to be a major contributor of overall soil microbial activity (Frankenberger and Dick, 1983). Among the different enzymes, dehydrogenase activity reflects the oxidative activity of total soil microflora and may be a good indicator of microbial activity (Biswas et al., 2017). Phosphatase enzyme plays an important role in transforming organic phosphorus into inorganic forms, suitable for plants.

Microorganisms and their mediated processes can give an integrated measure of soil health. The immense phenotypic and genetic diversity found in soil bacterial and fungal communities makes it one of the most difficult communities to study (Saxena et al., 2016). It has been suggested that at least $99 \%$ of bacteria observed under a microscope are not cultured by common laboratory techniques (Kirk et al., 2004). To overcome problems associated with non-culturable microbes, various methods have been developed to identify and study these microorganisms including numerous DNA and RNA-based methods including metagenomics, Phospholipids fatty acid analysis (PLFA), denaturing gel electrophoresis (DGGE) etc.

PCR targeting the 16S rDNA has extensively been used to study prokaryote diversity and allows identification of prokaryotes as well as the prediction of phylogenetic relationships (Kirk et al., 2004). In these methods, DNA is extracted from the environmental sample and purified. Restriction fragment length polymorphism (RFLP also known as amplified ribosomal DNA restriction analysis (ARDRA) is one of the tool used to study microbial diversity which relies on DNA polymorphisms. In a study by Liu et al. (1997) PCR amplified rDNA is digested with a 4-base pair cutting restriction enzyme. Different fragment lengths were detected using agarose or nondenaturing polyacrylamide gel electrophoresis in the case of community analysis (Tiedje et al., 1999). RFLP banding patterns can also be used to screen clones or used to measure bacterial community structure (Singh et al., 2015; Kim et al. 2016).

Under tropical condition very few studies have been conducted on long term effect of fertilizer and manure application on biological properties of soil. The studies on effect of long term soil management practices on microbial activity and diversity are needed for assessment of soil health. The Gangetic plains of India are one of the most intensively cultivated plains of the world. Therefore, objective of the present investigation was to study the long term effect of different management practices on activity and diversity of bacteria in a New Gangetic alluvial soil (Eutrocrept) under rice-wheat-jute cropping system.

\section{Materials and Methods}

Site description and treatment details : All India Coordinated Research Project on Long Term Fertilizer Experiment with ricewheat-jute cropping sequence was initiated in 1971 at the experimental farm of CRIJAF, Barrackpore, India. The experiment included three crops per year rice (AugustNovember), wheat (Nov-Mar) and jute (April-July) with 10 treatment combinations. The treatments were distributed in a randomized block design with four replications. For this study five different treatments were selected from this experiment and the treatments were: Fallow $\left(T_{1}\right)$, Control $\left(T_{2}\right), 100 \%$ recommended dose of NPK $\left(\mathrm{T}_{3}\right), 150 \%$ of recommended dose of NPK $\left(\mathrm{T}_{4}\right), 100 \%$ recommended dose of NPK plus farmyard manure $\left(T_{5}\right)$. The $100 \%$ recommended dose of NPK for rice and wheat was $120 \mathrm{~kg}$ $\mathrm{N}: 26 \mathrm{~kg} \mathrm{P}: 50 \mathrm{~kg} \mathrm{~K}$ and for jute was $60 \mathrm{~kg} \mathrm{~N}: 13 \mathrm{~kg} P: 50 \mathrm{~kg} \mathrm{~K}$ per hectare. The $150 \%$ NPK treatment comprised one and half times of the above doses of N, P and K, respectively. The N, P and K were applied to each crop in the sequence every year through urea, single super phosphate and muriate of potash, respectively. FYM @ of 10 tha $^{-1}$ was applied each year before the sowing of jute only once in a cropping cycle.

Soil sampling and soil enzymes analysis : To observe the long term effects of different management practices on soil microorganisms, soil samples were collected from each replicated plot of five treatments randomly from 3 spots after the harvest of wheat crop in the year 2012. Immediately after collection, the soil samples were preserved at $4^{\circ} \mathrm{C}$ till further studies on microbial population, enzyme activity and diversity analysis of bacteria completed. The enumeration of microbial population was done by standard method of serial dilution and spread plate technique. The plates were incubated at $30^{\circ} \mathrm{C}$ and counts were taken after 2 days of incubation. The results are reported as colony forming unit (CFU) per $g$ of dry sample. MBC was determined by chloroform fumigation and extraction method by Vance et al. (1987). Dehydrogenase activity and FDA hydrolase activity were determined using the method of Dick et al. (1996). Acid and alkali phosphatase enzyme activities were determined by the method of Tabatabai and Bremner (1969).

Isolation of bacteria from soils : The soil suspension of $10^{-2}$, $10^{-4}, 10^{-5}$ dilution prepared from soils of five treatments (fallow, control, $100 \%$ recommended dose of NPK, $150 \%$ of recommended dose of NPK fertilizer, $100 \%$ recommended dose of NPK plus farmyard manure) was spread plated on nine different media viz., solid nutrient agar media, Jensen agar media, King's B media, soil extract agar media, trypticase soy agar media, halophilic media and incubated for 2 days at $30^{\circ} \mathrm{C}$ (Verma et al., 2016). Oligotrophic microbes were isolated on 
nutrient agar medium diluted by 10 and 50 times. Bacillus and Bacillus derived genera were isolated using heat treatment at $80^{\circ} \mathrm{C}$ for $15 \mathrm{~min}$ and by spread plate method (Yadav et al., 2015). Based on morphology, distinct bacterial colonies were picked up and purified on respective growth medium. Colonies that appeared were purified by repeated streaking to obtain isolated colonies using respective medium plates. The pure cultures were maintained at $4^{\circ} \mathrm{C}$ as slant and as glycerol stock $(20 \%)$ at $-80^{\circ} \mathrm{C}$ for further use.

PCR amplification of 16S rRNA gene and amplified rDNA restriction analysis : Bacterial cultures were grown in nutrient broth for $24 \mathrm{hr}$ and genomic DNA was extracted by hexadecyltrimethyl ammonium bromide method described by Ivanova et al. (2000).

The quantity and quality of genomic DNA was checked on $0.8 \%$ agarose gel electrophoresis. Nearly full length $16 \mathrm{~S}$ rDNA was amplified using thermocycler (Biorad PTCO220 cycler) with a $25 \mu$ reaction mixture containing $50 \mathrm{ng}$ of genomic DNA, $0.2 \mathrm{mM}$ of each dNTP, $1 \mu \mathrm{M}$ of each primer, $2.5 \mathrm{mM}$ of $\mathrm{MgCl}_{2}$ and $1 \mathrm{U}$ of Taq DNA polymerase (Bangalore Genei, India) and buffer supplied with the enzyme. Universal primer 16Sf-5'AGAGTTTGATCCTGGCTCAG-3' and 16 sr-5' $^{\prime}$ AAGGAGGTGATCCAGCCGCA-3' were used for amplification using PCR conditions; initial denaturation at $95^{\circ} \mathrm{C}$ for $1 \mathrm{~min}, 35$ cycles consisting of $95^{\circ} \mathrm{C}$ for $1 \mathrm{~min}$ (denaturation) $52^{\circ} \mathrm{C}$ for $1 \mathrm{~min}$ (annealing) $72^{\circ} \mathrm{C}$ for $1 \mathrm{~min}$ (primer extension) and final extension $72^{\circ} \mathrm{C}$ for $1 \mathrm{~min}$. PCR products were separated by agarose gel electrophoresis on $1.5 \%$ agarose gel stained with ethidium bromide and documented in Alpha Imager TM1200 analysis system.

Approximately, $1 \mu \mathrm{gg}$ of PCR-amplified 16S rDNA fragments were restricted with endonuclease Hae III (Bangalore Genei, India) incubated at $37^{\circ} \mathrm{C}$ for overnight and resolved on 2.5 $\%$ agarose gels for 3 hrs. Banding pattern obtained were visualized by ethidium bromide staining and documented in Alpha Imager TM 1200 analysis system. Different phylotypes or operational taxonomic documentation units were obtained by similarity and clustering analysis using NTSYSpc-2.02e software. Similarity among the isolates was calculated by Jaccard's coefficient (Jacquard, 1912) and dendogram was constructed using UPGMA method (Nei and Li, 1979).

Statistical analysis : All the data generated was subjected to analysis of variance (ANOVA) and means were separated by Duncan's multiple range test at $P<0.05$ significance level using software, SPSS for Windows, Version 17.0. Chicago, SPSS Inc.

\section{Results and Discussion}

A total of 59 isolates were isolated from the soil under five different management practices using nine different growth media viz., nutrient agar, King's B, Jensen's N-free, soil extract agar, trypticase soy agar and halophilic media. Variation in bacterial population was observed in all media and treatments (Table 1). Among the nine growth media used for isolation, the maximum population was observed in nutrient agar medium (4.10 $\times 10^{7}$ to $\left.6.95 \times 10^{7}\right)$ followed by tryptic are soy agar $\left(4.30 \times 10^{7}\right.$ to $\left.5.96 \times 10^{7}\right)$ and the least population in halophilic medium $(2.10 \times$ $10^{3}$ to $4.50 \times 10^{3}$ ) (Table 1). More population in nutrient agar and trypticase soy agar may be due to the presence of rich complex nutrients, whereas halophilic medium containing $15 \% \mathrm{NaCl}$ showed bacterial population that are having the inherent potential to grow at high salt level. The average no. of bacteria per $\mathrm{g}$ of soil obtained from nutrient agar media was highest with 100\% NPK+FYM treatment. The number of oligotrophs obtained from ten and fifty times dilution of nutrient agar media was highest under $100 \% \mathrm{NPK}+\mathrm{FYM}$ treatment. The highest population of bacteria $\left(1.60 \times 10^{5}\right)$ was found in Jensen's $N$ free agar media from fallow treatment. The population from King's $B$ media varied from $0.85 \times 10^{5}$ to $1.98 \times 10^{5}$. The population of Bacillus varied from $2.50 \times 10^{5}$ to $4.80 \times 10^{5}$ and the highest number was in $100 \%$ $\mathrm{NPK}+\mathrm{FYM}$ treatment. The highest population of bacteria was obtained from trypticase soy agar media under 100\% NPK+FYM treatment.

Microbial biomass carbon content under different treatments varied from 221 to $447 \mathrm{mg} \mathrm{kg}^{-1}$ soil (Table 2). Distinct difference of microbial biomass carbon was observed among different treatments. Management practices like addition of manures, synthetic fertilizers and incorporation of crop residues strongly affected the microbial biomass corbon content of the soil (Basak et al., 2016). Among the treatments, low microbial biomass corbon content was observed under control and it increased significantly with fertilizer and manure application. Increase in microbial biomass corbon with addition of fertilizers and organic manure may be attributed to better crop growth, increased root biomass and root exudates (Shahid et al., 2013). Soil enzymes are the biological catalysts of innumerable reactions in soils. Some are interactive indices of biological activity in soil, and thus can be a good indicator of soil health. The enzyme activities viz., dehydrogenase, FDA hydrolase, acid and alkali phosphatase activities were studied and large variation were found under different treatments. Dehydrogenase activity varied from 2.8 to $7.4 \mathrm{~g} \mathrm{TPF} \mathrm{g}{ }^{-1}$ soil $24 \mathrm{hr}^{-1}$ and the highest value was associated with integrated treatment and lowest was with control. Optimum and balanced application of nutrients led to significant increase in dehydrogenase activity, while there was a slight reduction under the super optimal fertilized treatment $(150 \%$ NPK) (Table 2). This suggests that dehydrogenase activity is sensitive to the inhibitory effects associated with large amount of nitrogenous fertilizer additions (Masto et al., 2006). Continuous application of inorganic fertilizer integrated with FYM improved the organic matter status of soils, which in turn enhanced the enzymatic activity. NPK+FYM treatment recorded significantly higher dehydrogenase activity over all other treatments which might be due to a strong relationship between soil organic matter 
Table 1 : Long-term effect of manure and fertilization on bacterial population using various media in New Gangetic alluvial soil (Eutrocrept) under ricewheat-jute cropping sequence

\begin{tabular}{|c|c|c|c|c|c|c|c|c|c|}
\hline \multicolumn{4}{|c|}{ Treatments } & \multicolumn{6}{|c|}{ Bacterial population (CFU g ${ }^{-1}$ soil) } \\
\hline & $\overline{\mathrm{NA}}$ & NA 10 & NA 50 & SEA & $\overline{\mathrm{KB}}$ & JA & TSA & HM & Bacilli \\
\hline $\mathrm{T}_{1}$ & $4.65 \times 10^{7}$ & $2.15 \times 10^{6}$ & $2.05 \times 10^{6}$ & $2.47 \times 10^{5}$ & $0.85 \times 10^{5}$ & $1.60 \times 10^{5}$ & $4.50 \times 10^{7}$ & $3.50 \times 10^{3}$ & $3.20 \times 10^{5}$ \\
\hline $\mathrm{T}_{2}$ & $4.10 \times 10^{7}$ & $2.08 \times 10^{6}$ & $2.15 \times 10^{6}$ & $2.11 \times 10^{5}$ & $1.04 \times 10^{5}$ & $0.40 \times 10^{5}$ & $4.30 \times 10^{7}$ & $2.10 \times 10^{3}$ & $2.50 \times 10^{5}$ \\
\hline $\mathrm{T}_{3}^{2}$ & $5.58 \times 10^{7}$ & $2.75 \times 10^{6}$ & $2.12 \times 10^{6}$ & $2.85 \times 10^{5}$ & $0.98 \times 10^{5}$ & $0.44 \times 10^{5}$ & $5.55 \times 10^{7}$ & $3.10 \times 10^{3}$ & $3.40 \times 10^{5}$ \\
\hline $\mathrm{T}_{4}$ & $5.20 \times 10^{7}$ & $2.17 \times 10^{6}$ & $1.90 \times 10^{6}$ & $2.95 \times 10^{5}$ & $0.95 \times 10^{5}$ & $0.28 \times 10^{5}$ & $5.14 \times 10^{7}$ & $4.00 \times 10^{3}$ & $3.90 \times 10^{5}$ \\
\hline$T^{4}$ & $6.95 \times 107$ & $2.80 \times 10^{6}$ & $2.17 \times 10^{6}$ & $3.93 \times 10^{5}$ & $1.98 \times 10^{5}$ & $1.15 \times 10^{5}$ & $5.96 \times 10^{7}$ & $4.50 \times 10^{3}$ & $4.80 \times 10^{5}$ \\
\hline
\end{tabular}

NA- Nutrient agar; NA 10- Nutrient agar with 10 times dilution; NA 50- Nutrient agar with 50 times dilution; SEA- Soil Extract Agar; KB-King's B; JAJensen's Agar media, TSA-Tripticase Soy Agar; HM-Halophilic media; $T_{1}$ - Fallow; $T_{2}$ - Control; $T_{3}-100 \%$ recommended dose of NPK; $T_{4}-150 \%$ of recommended dose of NPK; $T_{5}-100 \%$ recommended dose of NPK plus farmyard manure

Table 2 : Long-term effect of manure and fertilization on microbial biomass carbon (MBC) and enzymatic activities in New Gangetic alluvial soil (Eutrocrept) under rice-wheat-jute cropping sequence

\begin{tabular}{|c|c|c|c|c|c|}
\hline Treatments & $\begin{array}{l}\text { MBC } \\
\left(\mathrm{mg} \mathrm{kg}^{-1}\right)\end{array}$ & $\begin{array}{l}\text { Dehydrogenase } \\
\left(\mu \mathrm{g} \text { TPF } \mathrm{g}^{-1} 24 \mathrm{hr}^{-1}\right)\end{array}$ & $\begin{array}{l}\text { FDA hydrolase } \\
\left(\mu \mathrm{g} \text { fluorescein } \mathrm{g}^{-1} \mathrm{hr}^{-1}\right)\end{array}$ & $\begin{array}{l}\text { Acid phosphatase } \\
\left(\mu \mathrm{gNPg} \mathrm{PN}^{-1} \mathrm{hr}^{-1}\right)\end{array}$ & $\begin{array}{l}\text { Alkaline } \\
\text { phosphatase } \\
\left(\mu \mathrm{gPNPg}{ }^{-1} \mathrm{hr}^{-1}\right)\end{array}$ \\
\hline$\overline{T_{1}}$ & $227^{\circ}$ & $3.4^{c}$ & $11.5^{d}$ & $141^{d}$ & $484^{d}$ \\
\hline $\mathrm{T}_{2}$ & $221^{\circ}$ & $2.8^{c}$ & $10.9^{d}$ & $139^{d}$ & $479^{d}$ \\
\hline $\mathrm{T}_{3}$ & $328^{\mathrm{b}}$ & $6.0^{b}$ & $13.9^{c}$ & $170^{\circ}$ & $579^{c}$ \\
\hline $\mathrm{T}_{4}^{3}$ & $331^{\mathrm{b}}$ & $5.7^{\mathrm{b}}$ & $16.1^{b}$ & $186^{\mathrm{b}}$ & $603^{b}$ \\
\hline $\mathrm{T}_{5}$ & $447^{\mathrm{a}}$ & $7.4^{\mathrm{a}}$ & $19.5^{\mathrm{a}}$ & $281^{a}$ & $624^{a}$ \\
\hline
\end{tabular}

$T_{1}$ - Fallow; $T_{2}$ - Control; $T_{3}-100 \%$ recommended dose of NPK; $T_{4}-150 \%$ of recommended dose of NPK; $T_{5}-100 \%$ recommended dose of NPK plus farmyard manure. Values followed by a same letter within a column are not significantly, different at $P<0.05$, according to Duncan's multiple range tests

content and enzyme activities (Mandal et al., 2007). FDA hydrolase activity varied from 10.9 to $19.5 \mu \mathrm{g}$ fluorescein $\mathrm{g}^{-1}$ soil $\mathrm{h}$ ${ }^{1}$ and highest with NPK+FYM treatment (Table 2). Hydrolysis of fluorescein esters has been used to measure microbial activity in environmental samples because it reflects protease, lipase and esterase activities (Tripathi et al., 2007). Similar to other enzymatic activities, continuous application of NPK+FYM resulted in significantly higher FDA over all the treatments. Alarge increase of FDA hydrolysis due to combined use of FYM and fertilizers could be attributed to increased microbial biomass resulting from continuous organic matter enrichment in soil. Acid and alkaline phosphatase activities in soil varied from 139 to 281 and 479 to $624 \mu \mathrm{g} \mathrm{p}$-nitrophenol $\mathrm{g}^{-1}$ soil hr $^{-1}$, respectively (Table 2). The highest value was with integrated treatment (NPK+FYM) and lowest was with control treatment. The acid phosphatase activity was much lower than alkaline phosphatase activity under all the treatments (Table 2), which might be due to the alkaline reaction of the soil (pH).

For the analysis of $16 \mathrm{~S}$ rDNA-RFLP data, the character state '1' was given for a band, which could be clearly and reproducibly detected in the gel and ' 0 ' was assigned if it was absent or it was not possible to determine. Gel electrophoresis of undigested PCR products revealed that isolates produced a single band of about $1540 \mathrm{bp}$ (Fig. 1). The data matrix thus generated was calculated by Jaccard's similarity coefficient for pair wise comparison. Dendrogram was constructed from the similarity matrix by the unweighted pair group method with arithmetic mean (UPGMA). The RFLP analysis revealed large variations among the isolates. Dendrogram was derived from the distance matrix by the UPGMA. A total of 35 clusters were grouped for 59 bacterial isolates (Fig. 2). Dendrogram was derived from all isolates and different treatments separately. It showed that a total of 35 clusters were grouped for 59 isolates (Fig. 2), 9 clusters out of 11 isolates (A) from 100\% NPK+FYM treatment, and 6 clusters out of 14 isolates (B) from control soil. The three treatments viz. 100\% NPK, 150\% NPK and fallow showed each of 7 clusters out of 9 isolates (C), 13 isolates (D) and 12 isolates $(E)$, respectively. It was observed that soil with $100 \%$ NPK+FYM treatment harboured the highest microbial diversity in the experimental field. While comparing the bacterial diversity under different treatments, it revealed that cultivation of land without fertilizer and manure caused a reduction in bacterial diversity from nine clusters to six clusters in control soil. The same number of clusters in three treatments viz., 100\% NPK, $150 \%$ NPK and fallow soil was due to the effect of soil type. In addition to crop type (Smalla et al., 2001), soil type or physical properties of soil can influence microbial diversity, in general, soil texture, in particular, have a greater effect on microbial community (Classen et al., 2015). The soil type of the present experimental site was 


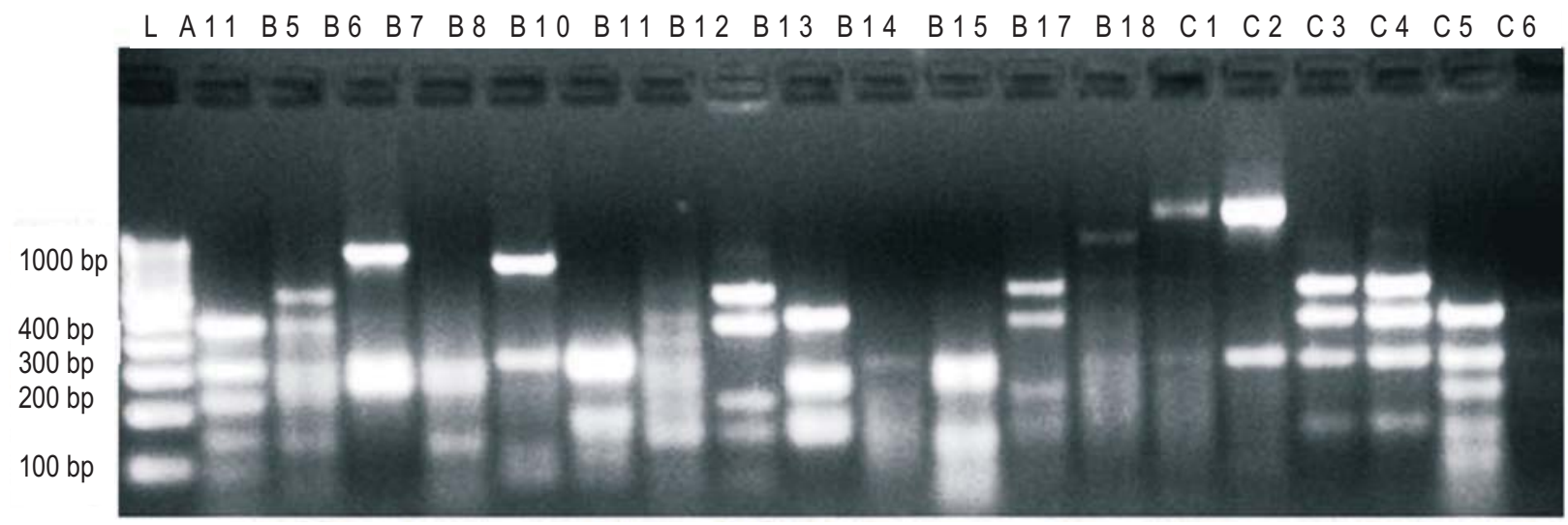

$\begin{array}{llllllllllllllllllll}\text { L C7 } & \text { C8 } & \text { C11 } & \text { C12 } & \text { C13 } & \text { C14 } & \text { C15 } & \text { C16 } & \text { C18 } & \text { D4 } & \text { D6 } & \text { D7 } & \text { D9 } & \text { D11 } & \text { D12 } & \text { D13 } & \text { D14 } & \text { D15 } & \text { D17 }\end{array}$
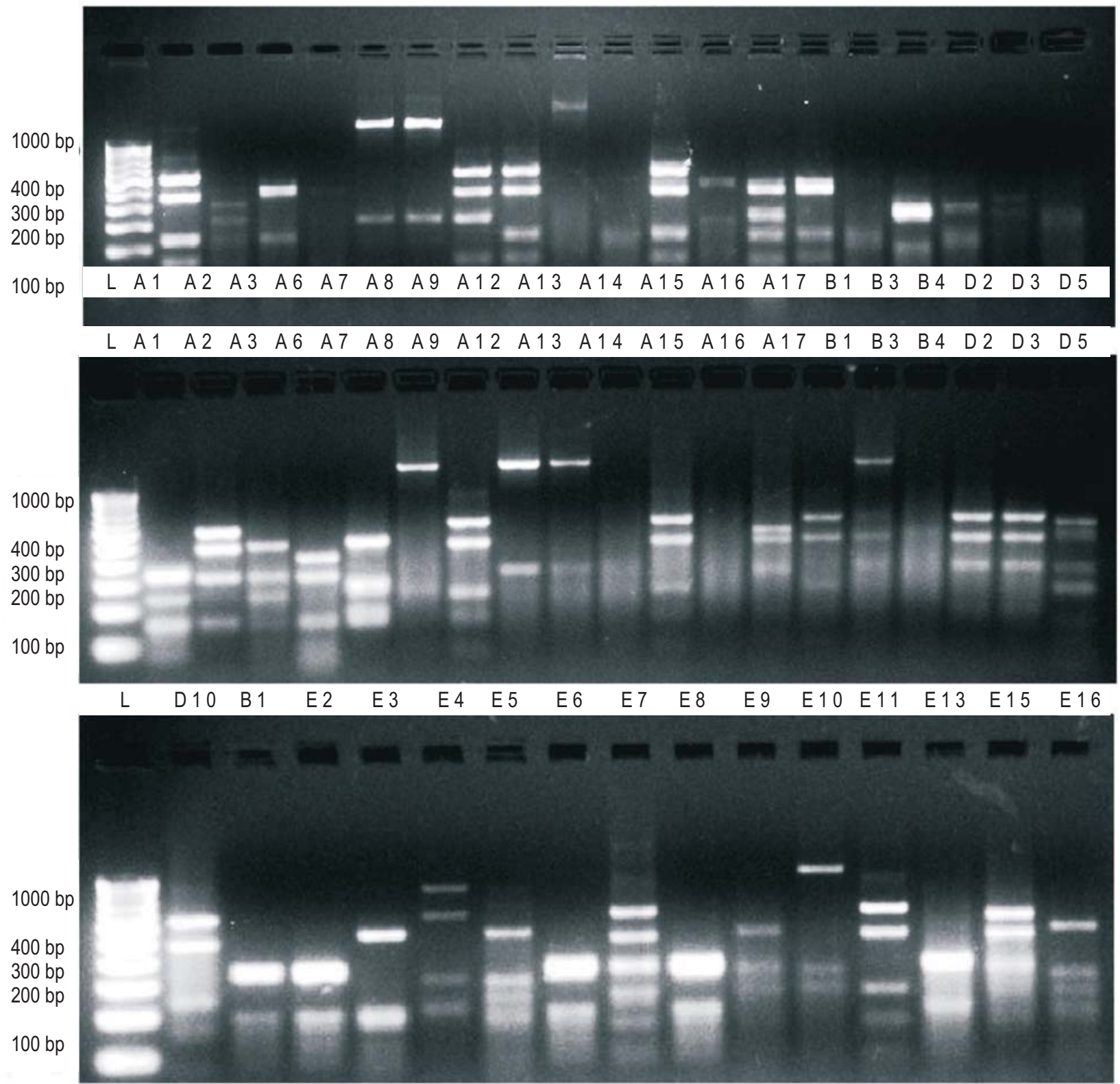

Fig. 1 : Restriction patterns of the amplified 16S rRNA gene of bacterial isolates generated using one restriction endonucleases Hae III 


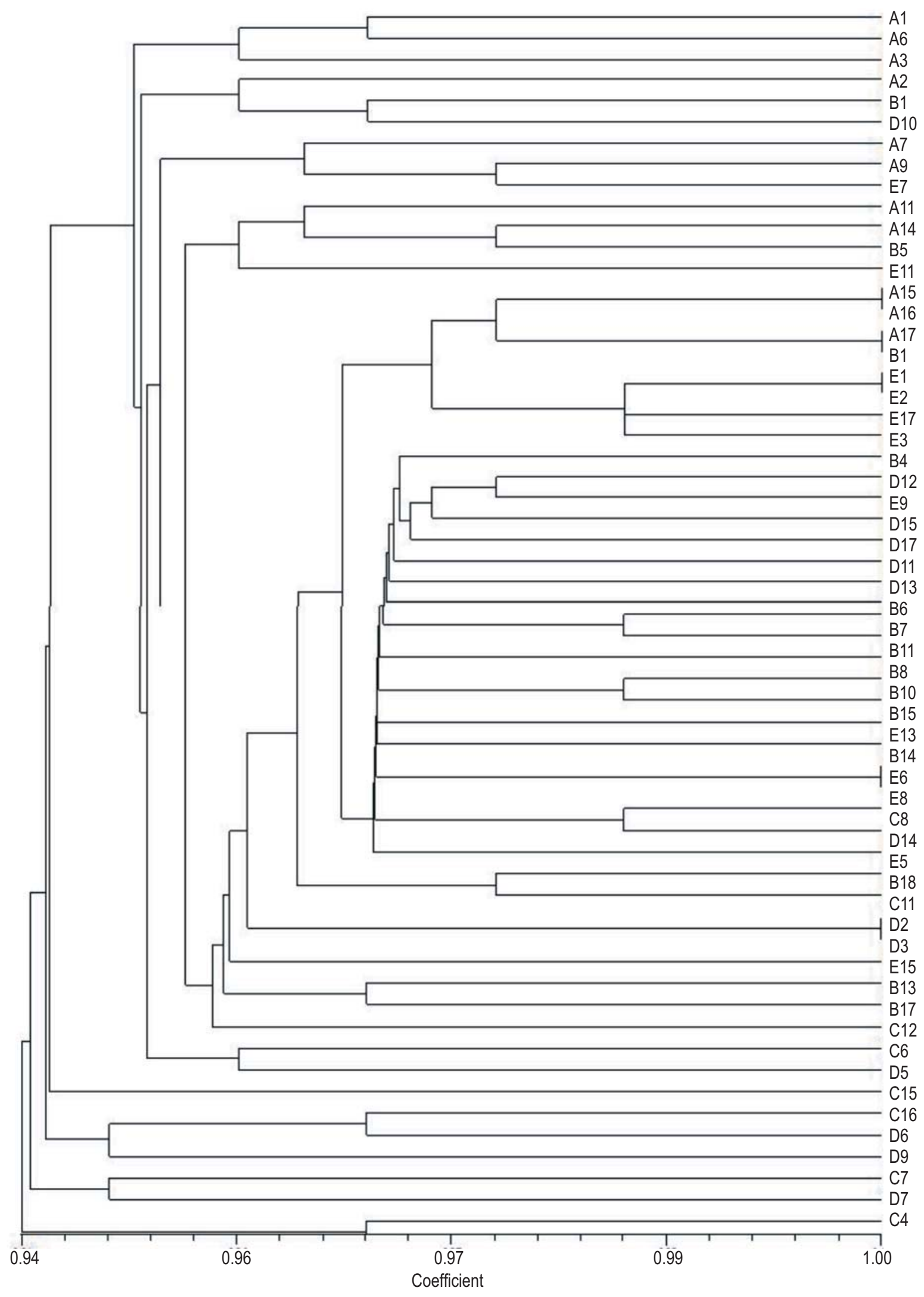

Fig. 2 : Dendrogram of bacterial isolates selected from all five treatments based on cluster analysis of RFLP products with restriction endonuclease Hae III using UPGMA algorithm and Jaccard coefficient 
sandy loam which probably nullified the effect of fertilization on bacterial diversity. This is supported by the findings of Johnson et al. (2003) who observed that bacterial fingerprints from similar soil types collected from places within $2 \mathrm{~km}$, but with different land use, are also similar. Lower diversity in control soil is due to minimal stress in control soil. Moreover, fertilization promoted the growth of variety of microbes directly by providing nutrients or indirectly by stimulating plant growth and enhancing root carbon flow. This corroborates the findings of O'Donnell et al. (2001) who established that fertilizers as the driver of change in microbial diversity. When compared with mineral fertilization or unfertilized control, organic manure showed more superiority for enriching the richness and diversity of soil bacteria (He et al., 2008), which might be due to the enhanced soil microbial biomass and activities in organic treated soils (Islam et al., 2011).

Thus, long-term application of manures and fertilizers had describable impacts on extracellular enzyme activity, microbial diversity of soil. Soil with integrated treatment (100\% NPK $+\mathrm{FYM}$ ) showed highest microbial biomass carbon and extracellular enzyme activities and microbial diversity. The present study showed that maximum number of cluster of bacterial isolates was found in the soil with integrated treatment. Therefore, balanced fertilization with mineral fertilizers and organic manures harbour diverse group of bacteria in soil which may be favourable to sustain soil productivity and maintain soil health.

\section{Acknowledgments}

Authors are grateful to the Director, ICAR-Central Research Institute for Jute and Allied Fibres, Barrackpore, Kolkata and Director, ICAR-Indian Agricultural Research Institute, New Delhi for providing necessary facilities and financial support for the study and the first author is extremely grateful to Dr. T. J. Purakayastha, Principal scientist, Division of Soil Science and Agricultural Chemistry, ICAR-IARI, New Delhi for his valuable suggestions and kind help for the preparation of the manuscript.

\section{References}

Basak, N., A. Datta, T. Mitran, B. Mandal and P.K Mani: Impact of organic and mineral inputs onto soil biological and metabolic activities under a long-term rice-wheat cropping system in subtropical Indian Inceptisols. J. Environ. Biol., 37, 83-89 (2016).

Biswas, S., G.C. Hazra, T.J. Purakayastha, N. Saha, T. Mitran, S.S. Roy, N. Basak and B. Mandal: Establishment of critical limits of indicators and indices of soil quality in rice-rice cropping systems under different soil orders. Geoderma, 292, 34-48 (2017).

Classen, A.T., M. K. Sundqvist, J. A. Henning, G. S. Newman, J. A. M. Moore, M. A. Cregger and L. C. M. Courtney: Direct and indirect effects of climate change on soil microbial and soil Microbialplant interactions: What lies ahead? Ecosphere., doi:10.1890/ES 1500217.1 (2015)

Dick, R.P., D.P. Breakwell and R.E Turco: Soil enzyme activities and biodiversity measurements and integrative microbiological indicators. In: Methods for assessing soil quality (Eds.: J. W. Doran and A.J. Jones) pp. 247-271 (1996).

Frankenberger, W.T. and W.A Dick: Relationships between enzyme activities and microbial growth and activity indices in soil. Soil Sci. Soc. Am. J., 47, 945-951 (1983).

He, J.Z., Y. Zheng, C.R. Chen, Y.Q. He and L.M. Zhang: Microbial composition and diversity of an upland red soil under long-term fertilization treatments as revealed by culture-dependent and culture-independent approaches. J. Soils. Sed., 8, 349-358 (2008).

Islam, M.R., P.S. Chauhan, Y. Kim, M. Kim and T. Sa: Community level functional diversity and enzyme activities in paddy soils under different long-term fertilizer management practices. Biol. Fertility Soils, 47, 599-604 (2011).

Ivanova, I., P. Kabadjova, A. Pantev, S. Danova and X. Dousset: Detection, purification and partial characterization of a novel bacteriocin substance produced by Lactoccous lactis subsp. lactis b14 isolated from Boza-Bulgarian traditional cereal beverage. Biocatalysis, 41, 47-53 (2000).

Jaccard, P.: The distribution of the flora in the alpine zone. New Phytol., 11,37-50 (1912).

Jhonson, M.J., K.Y. Lee and K.M. Scow: DNA fingerprinting reveals links among agricultural crops, soil properties, and the composition of soil microbial communities. Geoderma, 114, 279-303 (2003).

Kim, K., R. Islam, A. Benson, M.M. Joe, W. Denver, M. Chanratan, P. Chatterjee, Y. Kang and T. Sa: An overview of different techniques on the microbial community structure, and functional diversity of plant growth promoting bacteria. Korean J. Soil Sci. Fert., 49, 144156 (2016).

Kirk, J.L., L.A. Beaudette, M. Hart, P. Moutoglis, J.N. Klironomos, H. Lee and J.T. Trevors: Methods of studying soil microbial diversity. J. Microbiol. Methods, 58, 169-188(2004).

Liu, W.T., T.L. Marsh, H. Cheng and L.J. Forney: Characterization of microbial diversity by determining terminal restriction fragment length polymorphisms of genes encoding 16S rRNA. Appl. Environ. Microbiol., 63, 4516-4522 (1997).

Mandal, A., A. K. Patra, D. Singh, A. Swarup and R. E. Masto: Effect of long-term application of manure and fertilizer on biological and biochemical activities in soil during crop development stages. Biores. Technol., 98, 3585-3592 (2007).

Masto, R.E., P.K. Chhonkar, D. Singh and A.K. Patra: Changes in soil biological and biochemical characteristics in a long-term field trial on a sub-tropical inceptisol. Soil Sci. Soc. Am. J., 38, 1577-1582 (2006).

Nei, M. and W.H. Li: Mathematical model for studying genetic variation in terms of restriction endonucleases. PNAS, 76, 5269-5273 (1979).

O'Donnell, A.G., M. Seasman, A. Macrae, I. Waite and J.T. Davies: Plants and fertilizers as drivers of change in microbial community structure and function in soils. Plant Soil, 232, 135-145 (2001).

Saxena, A.K., A.N. Yadav, M. Rajawat, R. Kaushik, R. Kumar, M. Kumar, R. Prasanna and L. Shukla: Microbial diversity of extreme regions: An unseen heritage and wealth. Indian J. Plant. Genet. Res., 29, 246-248 (2016).

Shahid, M., A.K. Nayak, A.K. Shukla, R. Tripathi, A. Kumar, S. Mohanty, P. Bhattacharyya, R. Raja and B.B. Panda: Long-term effects of fertilizer and manure applications on soil quality and yields in a sub-humid tropical rice-rice system. Soil Use Manag., 29, 322-332 (2013).

Singh, B.P.: Molecular and functional diversity of PGPR fluorescent 
Pseudomonas based on $16 \mathrm{~S}$ rDNA-RFLP and RAPD markers. J. Environ. Biol., 36, 1169-1178 (2015).

Smalla, K., G. Wieland, A. Buchner, A. Zuck and G. Berg: Bulk and rhizosphere soil bacterial communities studied by denaturing gradient gel electrophoresis. Appl. Environ. Microbiol., 67, 47424751 (2001).

SPSS Inc. SPSS version 17.0, Chicago, IL(1999).

Tabatabai, M.A. and J.M. Bremner: Use of P-nitrophenyl phosphate for assay of soil phosphatase activity. Soil Biol. Biochem., 1, 301-307 (1969).

Tripathi, S., A. Chakraborty, K. Chakraborti and B.K. Bandyopadhyay: Enzyme activities and microbial biomass in coastal soils of India. Soil Biol. Biochem., 39, 2840-2848 (2007).

Vance, E.D., P.C. Brookes and D.S. Jenkinson: An extraction method for measuring soil microbial biomass carbon. Soil Biol. Biochem., 19,
703-707 (1987).

Verma, P., A.N. Yadav, K.S. Khannam, S. Mishra, S. Kumar, A.K. Saxena and A. Suman: Appraisal of diversity and functional attributes of thermotolerant wheat associated bacteria from the peninsular zone of India. Saudi J. Biol. Sci., doi:10.1016/j.sjbs.2016.01.042 (2016).

Yadav, A.N., P. Verma, M. Kumar, K.K. Pal, R. Dey, A. Gupta, J.C. Padaria, G.T. Gujar, S. Kumar and A. Suman: Diversity and phylogenetic profiling of niche-specific Bacilli from extreme environments of India. Ann. Microbiol., 65, 611-629 (2015).

Zhao, J., T. Ni, J. Li, Q. Lu, Z. Fang, Q. Huang, R. Zhang, R. Li, B. Shen and $Q$. Shen: Effects of organic-inorganic compound fertilizer with reduced chemical fertilizer application on crop yields, soil biological activity and bacterial community structure in a rice-wheat cropping system. Appl. Soil Ecol., 99, 1-12 (2016). 